\title{
Knowledge of HIV-AIDS a dominant factor of antiretroviral therapeutic adherence in women with HIV-AIDS
}

\author{
Surilena* and Jean Valeri**
}

\begin{abstract}
\section{BACKGROUND}

Antiretroviral therapy adherence (ART adherence) is a factor significantly extending life expectancy of people living with HIV/AIDS. The objective of this study was determine several factors on ART adherence in women infected with HIV/AIDS.
\end{abstract}

\section{METHODS}

A cross-sectional study involving 99 women with HIV/AIDS who were infected through their sexual partner or spouse was conducted in Dharmais Hospital between March and August 2014. The instruments used were demographic and self-esteem questionnaires, Hamilton rating scale for depression, Hamilton rating scale for anxiety, knowledge, perception of ART benefits and limitations, family support, peer support as well as assessment of ART adherence. The knowledge questionnaire has been validated with Cronbach's alpha $=0.823$. Data were analyzed using ChiSquare test and multivariate logistic regression.

\section{RESULTS}

A total of 99 women with HIV/AIDS participated in the study, with an age range of 30- 60 years and mean age of $36 \pm 3.72$ years. A total of $57.58 \%$ of participants showed poor ART adherence. Multivariate logistic regression analysis showed that knowledge, ART side effects, depression, peer support and ARV availability significantly affected ART adherence $(\mathrm{p}<0.05)$. The most dominant factor affecting ART adherence was knowledge, with OR $=64.02$ (95\% CI 4.99-670.12).

\section{CONCLUSION}

With good knowledge about HIV/AIDS infection, ART benefits, and possible ARV side effects, women living with HIV/AIDS are expected to carry out ART adherence according to the recommended rules.

Keywords: Antiretroviral therapy, adherence, knowledge of HIV-AIDS, HIV/AIDS, women
*Psychiatric Department,

Faculty of Medicine,

Atma Jaya Catholic University of Indonesia

**Medical Profession Program,

Faculty of Medicine,

Atma Jaya Catholic University of

Indonesia

\section{Correspondence:}

Dr. dr. Surilena, $\operatorname{SpKJ}(\mathrm{K})$

Psychiatric Department,

Faculty of Medicine,

Atma Jaya Catholic University of

Indonesia

Jl. Pluit Raya No. 2,

Jakarta 14440.

Email: surilenahasan@yahoo.co.id /

surilena@atmajaya.ac.id

Phone: +62812-9457690

Univ Med 2015;34:129-37

DOI: 10.18051/UnivMed.2016.v35.129-137 pISSN: 1907-3062 / eISSN: 2407-2230

This open access article is distributed under a Creative Commons Attribution-Non Commercial-Share Alike 4.0 International License 


\section{Pengetahuan tentang HIV/AIDS merupakan faktor dominan terhadap kepatuhan terapi antiretroviral pada perempuan terinfeksi HIV/AIDS}

\section{ABSTRAK}

\section{LATAR BELAKANG}

Kepatuhan terapi antiretroviral (ART) merupakan salah satu faktor yang dapat memperpanjang umur harapan hidup orang dengan HIV/AIDS secara bermakna. Penelitian ini bertujuan untuk menentukan beberapa faktor yang berperan terhadap kepatuhan ART pada perempuan yang terinfeksi HIV/AIDS.

\section{METODE}

Studi cross-sectional pada 99 perempuan yang terinfeksi HIV/AIDS dari pasangan seksual atau pasangan tetapnya, dan dilaksanakan di Unit Terpadu AIDS RS Dharmais, antara bulan Maret-Agustus 2014. Instrumen yang digunakan pada penelitian ini adalah kuesioner demografik, self-esteem questionnaire, Hamilton rating scale for depression, Hamilton rating scale for anxiety, pengetahuan, persepsi manfaat ART, persepsi hambatan ART, dukungan keluarga, dukungan teman sebaya dan kepatuhan ART. Kuesioner pengetahuan telah di validasi dengan nilai Cronbach's alpha sebesar 0,823. Data di analisis dengan Chi-Square test dan regersi logistik ganda.

HASIL

Sebanyak 99 perempuan dengan HIV/AIDS berpartisipasi dalam studi dengan rentang usia 30-60 tahun dan rerata usia adalah $36 \pm 3,72$ tahun. Sebanyak 57,58\% responden menunjukkan kepatuhan ART buruk. Analisis regresi logistik ganda menunjukkan bahwa pengetahuan, efek samping ART, depresi, dukungan sebaya dan ketersediaan ARV memiliki hubungan yang signifikan terhadap kepatuhan ART ( $p<0,05)$. Faktor yang paling dominan yang mempengaruhi kepatuhan ART adalah pengetahuan dengan nilai OR =64,02 (95\% CI 4,99-670,12).

\section{KESIMPULAN}

Pengetahuan yang baik tentang infeksi HIV/AIDS, manfaat ART dan efek samping obat ARV yang dapat terjadi, diharapkan perempuan yang mengalami infeksi HIVIAIDS mampu menjalankan kepatuhan ART sesuai aturan yang dianjurkan.

Kata kunci: Terapi antiretroviral, kepatuhan, pengetahuan tentang HIV/AIDS, HIV/AIDS, perempuan

\section{INTRODUCTION}

The United Nation global report on the AIDS epidemic showed that there are 1.7 million women in Asia infected with HIV and $35 \%$ of them are infected from their sexual partner or their spouse. The number of women infected with HIV/AIDS is increasing each year along with the increase in the number of men doing unsafe sex, who eventually will transmit HIV/AIDS to their sexual partner or spouse. ${ }^{(1)}$ The Indonesian Ministry of Health reported that in 2010 there were 404.600 people with HIV/AIDS (among whom $42 \%$ women). ${ }^{(2)}$ In 2014, the Indonesian Ministry of Health reported that there were 64\% men and $36 \%$ women $(6,539$ housewives) infected with HIV/AIDS. ${ }^{(3)}$ Increased HIV transmission to housewives can increase the risk of transmission to their infants, which consequently results in increased perinatal AIDS patients. ${ }^{(2,3)}$

The psychosocial burden of housewives infected with HIV/AIDS is larger than their physical burden, ranging from changes in selfimage, transmission of HIV/AIDS to their husband and children and the guilt felt after the 
death of the husband or the children, becoming the bread winner after the death of the husband. The psychosocial burden of the women will extremely affect their survival and may cause emotional and mental health problems, which may lead to mental emotional disorder and poor medication adherence. ${ }^{(4)} \mathrm{A}$ study demonstrated that $45 \%$ of people living with HIV/AIDS who experienced depression had poor medication adherence compared to $25 \%$ of those who did not. Depressive disorders can increase risky behaviors that facilitate HIV transmission to others, because dormant HIV can become active again and depression accelerates the rate of HIV disease. ${ }^{(5)}$

The Indonesian National AIDS Commission in 2011 reported that the program of HIV/AIDS care and treatment in Indonesia is still not effective. The commission estimated that the number of people living with HIV in Indonesia was around 300,000, yet those who received ART were only 30,000 people and about 200,000 people were thought to be infected with HIV/ AIDS but had not been diagnosed, since they had not undergone HIV tests. ${ }^{(6)}$ In 2012, the Indonesian Ministry of Health reported that a decrease in ART adherence was associated with increased morbidity and hospital admissions as well as increased costs of care. Poor adherence to antiretroviral therapy is one of the most important factors that prevent successful HIV/ AIDS treatment. ${ }^{(3,6)}$

Antiretroviral therapy must be continued for life and adherence is necessary. A good level of adherence of $\geq 95 \%$ is required to obtain successful antiretrovital therapy. A high adherence level is quite difficult to maintain after long term treatment. ${ }^{(7)}$ There are some factors affecting ART adherence, including internal and external factors. Internal factors include age, educational level, survival motivation, perception about HIV/AIDS and ART, depression, anxiety, beliefs, self-image, self-esteem, self-efficacy, and presenting opportunistic infections, while external factors are level of knowledge, family economic status, support from the case manager, medical team, society, and family, ARV medication availability, access to ART health care, ART side effects, stigma and discrimination. ${ }^{(6,7)}$ Our study aimed to determine factors affecting ART adherence such as knowledge, depression, anxiety, perception about ART benefits and limitations, self-esteem, family support, peer support, ART side effects, and ARV availability, in women infected from their sexual partner or spouse.

\section{METHODS}

\section{Research design}

A cross-sectional study was conducted on women infected with HIV/AIDS who visited the outpatient clinic of AIDS Comprehensive Diagnostic Unit at Dharmais Hospital between March and August 2014.

\section{Research subjects}

The inclusion criteria were women infected with HIV/AIDS through their partner/spouse, aged 30-60 years, literate in the Indonesia langguage or able to read and write, and without history of substance abuse/alcohol dependency or abuse, and had ongoing ARV therapy. The exclusion criteria were women with psychosis, and those who refused to sign informed consent. The sampling technique was by consecutive nonrandom sampling; with an anticipated 10\% drop out, the number of respondents was 99 women infected with HIV/AIDS. ${ }^{(8)}$

\section{Measurements}

The respondent filled in demographic and self-esteem questionnaires, ${ }^{(9)}$ the latter consisting of 10 questions with four possible answers, with a score of $\geq 15$ for high self-esteem and a score of $<15$ for low self-esteem. The Hamilton rating scale for depression/HDRs ${ }^{(10)}$ consists of 17 questions, with a score of $<7$ indicating negative depression, and a score of $\geq 7$ indicating positive depression. The Hamilton rating scale for anxiety/HARs ${ }^{(11)}$ consists of 14 questions, a score of 0-13 indicating negative anxiety and a 
score of $\geq 14$ positive anxiety. The peer support test ${ }^{(12)}$ consists of 10 questions, with a score of $\geq 12$ for positive peer support, and a score of $<12$ for negative peer support. All instruments in this study have been previously validated, including the knowledge questionnaire with Cronbach's Alpha of 0.823 and the ART adherence questionnaires (self-report), with a sensitivity of $94.4 \%$, specificity $88.9 \%$, and a cutoff value of 95 ( $>95 \%$ good ART adherence and $<95 \%$ low adherence). ${ }^{(13)}$ The knowledge questionnaire consists of 23 questions with three possible answers, a total score of $\leq 29$ indicating poor knowledge, a score of $\geq 30-45$ indicating moderate knowledge, and a score of $\geq 46$ indicating good knowledge. ${ }^{(13)}$

\section{Statistical analysis}

In this study, bivariate analysis was performed using Chi Square test and multivariate analysis using stepwise logistic regression. Statistical analysis was done using SPSS software program version 17.0.

\section{Ethical clearance}

This research fulfilled the International Ethical Guidelines for ethical review in the Faculty of Medicine, Atma Jaya Catholic University.

\section{RESULTS}

In this study, there were 99 women who were infected with HIV/AIDS through their partner/spouse, with age range of 30-60 years and mean age of $36.03 \pm 3.72$ years. In this study there were no respondents who dropped out. The majority of subjects had the following characteristics: high school graduates (44.4\%), married (98.7\%), housewives (54.5\%), medium income $(57.6 \%)$, and more than one child $(82.8 \%)$. In the study, ART adherence was measured by the self-report. There were 57 $(57.6 \%)$ subjects with poor ART adherence $(<95 \%)$ (Table 1).
Table 1. Socio-demographic characteristics and ART adherence

\begin{tabular}{|c|c|}
\hline Variables & $n(\%)$ \\
\hline \multicolumn{2}{|l|}{$\begin{array}{l}\text { Socio-dem ographic } \\
\text { characteristics }\end{array}$} \\
\hline Age (yrs) & $\begin{array}{c}\text { Range 30-60 } \\
(\text { Mean } 36.03 \pm 3.72)\end{array}$ \\
\hline $30-39$ & $60(60.6)$ \\
\hline $40-49$ & $25(25.3)$ \\
\hline $50-59$ & $11(11.1)$ \\
\hline$\geq 60$ & $3(3.03)$ \\
\hline \multicolumn{2}{|l|}{ E ducational level } \\
\hline $\mathrm{High}$ & $44(44.4)$ \\
\hline Moderate & $37(37.4)$ \\
\hline Low & $18(18.2)$ \\
\hline \multicolumn{2}{|l|}{ Occupation } \\
\hline $\begin{array}{l}\text { Empl oyed } \\
\text { Unemployed } \\
\text { (housewives) }\end{array}$ & $\begin{array}{l}45(45.5) \\
54(54.5)\end{array}$ \\
\hline \multicolumn{2}{|l|}{ Marital status } \\
\hline Married & $97(98.7)$ \\
\hline Unm aried & $2(2.3$ \\
\hline \multicolumn{2}{|l|}{ Number of children } \\
\hline 0 & $17(17.2)$ \\
\hline$>1$ & $82(82.8)$ \\
\hline \multicolumn{2}{|l|}{$\begin{array}{l}\text { Number of children } \\
\text { infected withHIV/AIDS }\end{array}$} \\
\hline 0 & $95(96.2)$ \\
\hline$\geq 1$ & $4(3.8)$ \\
\hline \multicolumn{2}{|l|}{ Socioeconomic status } \\
\hline Medium & $57(57.6)$ \\
\hline Low & $42(42.4)$ \\
\hline ART actherence & \\
\hline $\begin{array}{l}\geq 95 \% \\
\text { (high ART actherence) }\end{array}$ & $42(42.4)$ \\
\hline $\begin{array}{l}<95 \% \\
\text { (10w ART adherence) }\end{array}$ & $57(57.6)$ \\
\hline
\end{tabular}

ART : anti retroviral therapy

Chi-Square analysis showed that knowledge, perception of ART benefits and side effects, self-esteem, depression, peer support, ART availability, have a significant effect on ART adherence $(\mathrm{p}<0.05)$. Chi-Square analysis also showed that perception of ART limitations, anxiety, and access to ART did not have a significant effect on ART adherence $(\mathrm{p}>0.05)$ (Table 2). This study showed that $60.6 \%$ of the subjects had moderate knowledge about the category of HIV/AIDS infection, ART benefits and side effects, with $56.7 \%$ of subjects having 
Table 2. Association between factors affecting ART adherence $(n=99)$

\begin{tabular}{|c|c|c|c|c|}
\hline \multirow{2}{*}{$\begin{array}{l}\text { Factors affecting an tiretroviral } \\
\text { therapeutic adherence }\end{array}$} & & \multicolumn{2}{|c|}{ ART adherence } & \multirow[b]{2}{*}{$\mathbf{p}$} \\
\hline & & $\begin{array}{c}\text { Good }(n=42) \\
(n, \%)\end{array}$ & $\begin{array}{c}\text { Po or }(n=57) \\
(n, \%)\end{array}$ & \\
\hline \multirow[t]{3}{*}{ Knowledge } & Good & $10(50.0)$ & $10(500)$ & \\
\hline & Moderate & $26(43.3)$ & $34(567)$ & $0.000 *$ \\
\hline & Poor & $6(31.6)$ & $13(68.4)$ & \\
\hline \multirow[t]{3}{*}{ Perception of ART benefits } & Good & $6(49.0)$ & $9(60.0)$ & \\
\hline & Moderate & $22(43.1)$ & $29(569)$ & $0.001 *$ \\
\hline & Poor & $14(42.4)$ & $19(576)$ & \\
\hline \multirow[t]{3}{*}{ Perception of ART limitations } & High & $6(28.6)$ & $15(71.4)$ & \\
\hline & Moderate & $31(41.3)$ & $24(58.7)$ & 0.101 \\
\hline & Low & $5(21.7)$ & $18(783)$ & 0.101 \\
\hline \multirow[t]{2}{*}{ ExperiencedART side effects } & Absent & $32(78.0)$ & $9(32.0)$ & $0.004 *$ \\
\hline & Present & $10(17.2)$ & $48(828)$ & \\
\hline \multirow{2}{*}{ Self esteem } & High & $27(60.0)$ & $18(400)$ & $0.000 *$ \\
\hline & Low & $15(27.8)$ & $39(712)$ & \\
\hline \multirow{2}{*}{ Depression } & Negative & $35(77.8)$ & $10(222)$ & $0.003^{*}$ \\
\hline & Postive & $7(12.9)$ & $47(77.1)$ & \\
\hline \multirow[t]{2}{*}{ Anxiety } & Negative & $19(51.4)$ & $18(586)$ & 0.302 \\
\hline & Positive & $23(37.1)$ & $39(629)$ & \\
\hline \multirow[t]{2}{*}{ Peer support } & Present & $18(64.3)$ & $10(357)$ & \\
\hline & Absent & $24(33.8)$ & $47(662)$ & $0.002 *$ \\
\hline \multirow[t]{3}{*}{ Easy acces to ART } & Good & $10(52.6)$ & $9(47.4)$ & \\
\hline & Moderate & $26(76.5)$ & $8(23.5)$ & 0.756 \\
\hline & Poor & $6(13.1)$ & $40(869)$ & \\
\hline \multirow[t]{2}{*}{ ARV availability } & High & $36(56.3)$ & $28(437)$ & $0.001 *$ \\
\hline & Low & $6(17.1)$ & $29(829)$ & \\
\hline
\end{tabular}

${ }^{*} \mathrm{p}<0.05 ;$ ART : anti retroviral therapy

low ART adherence. A total of $32.4 \%$ of the subjects claimed not to know the timeline of progression of HIV infection to AIDS if not given treatment, 54\% lacked understanding of antiretroviral drug resistance, and $38 \%$ did not know the side effects of antiretroviral drugs and the duration of antiretroviral therapy that has to be followed (Table 2). This study showed that subjects with poor perception of the benefits of ART had poor ART adherence (57.6\%). Hence, $19 \%$ of the subjects stated to lack confidence that ART therapy is beneficial for the disease and would not reduce the risk of opportunistic infections (tuberculosis, herpes, and others). Most subject perceptions regarding ART limitations $(55.6 \%)$ were in the moderate category and $58.7 \%$ of subjects had poor ART adherence. There were $51.2 \%$ of subjects who reported being bored by routine therapy, $41 \%$ found it difficult to stop ART implementation and $39 \%$ of subjects were afraid of becoming unemployed because they were often absent from work to undergo ART (Table 2). This study showed that of the subjects who experienced ART side effects, $82.8 \%$ had poor ART adherence. In this study, $64.7 \%$ of subjects had a high score for the category of availability of antiretroviral drugs and $43.7 \%$ had low ART adherence. Regarding access to ART, the majority of subjects (46.5\%) had a poor access to ART and $86.9 \%$ had low ART adherence. The subjects claimed that ARV drugs are given free by the Indonesian government, but that hospital administration, other drugs, and laboratory tests are quite expensive, the cost of which they have to pay themselves. The subjects also had to spend quite expensive transportation costs of around Rp 35,000-40,000 per hospital visit (Table 2). 
Table 3. Multivariate analysis assessing the association of several variables and ART adherence

\begin{tabular}{lcccccccc}
\hline \multicolumn{1}{c}{ Variables } & B & S.E. & Wald & df & Sig & OR & \multicolumn{2}{c}{$\begin{array}{c}\text { 95\%C I for } \\
\text { EXP(B) }\end{array}$} \\
\hline Poor knowledge & & & & & & & Lower & Upper \\
Moder ate knowledge & 0.890 & 0.345 & 3.456 & 1 & 0.003 & 6.33 & 1.008 & 21.890 \\
Good knowledg & 1.654 & 0.767 & 6.234 & 1 & 0.000 & 64.02 & 4.998 & 670.120 \\
Experienced si de effects of ART & 1.908 & 1.023 & 4.767 & 1 & 0.001 & 22.06 & 1.456 & 83.275 \\
Depressi on & 2.228 & 0.980 & 1.897 & 1 & 0.000 & 57.07 & 1.077 & 12.345 \\
Peer apport & 2.223 & 1.240 & 3.233 & 1 & 0.003 & 46.01 & 1.098 & 13.678 \\
ARV availability & 2.224 & 1.075 & 2.988 & 1 & 0.001 & 12.18 & 1.890 & 68.210 \\
Constant & 2.579 & 2.188 & 2.122 & 1 & 0.123 & 0.023 & & \\
\hline
\end{tabular}

The subjects with low self esteem and poor ART adherence accounted for $71.2 \%$. Subjects with anxiety disorders $(62.6 \%)$ tended to have poor ART adherence, and $77.1 \%$ of subjects had depression and poor ART adherence. (Table 2). In this study, the majority of subjects $(71.7 \%)$ did not have peer support. Poor adherence is more prevalent in subjects without peer support $(66.2 \%)$ than in subjects with peer support (35.7\%). The subjects claimed that they were not sure where to go to get the support of their peers and that they needed the support of other friends who are infected with HIV/AIDS or who are not infected, of people in the neighborhood, to share information about HIV/AIDS and its treatment and support each other, to remind them to take antiretroviral drugs regularly and not do it furtively, to provide loans in case of a shortage of antiretroviral drugs, so that they may optimistically face their HIV/AIDS and be motivated on a regular basis, especially with regard to antiretroviral treatment (Table 2).

Multiple logistic regression analysis showed that there were five significant variables $(\mathrm{p}<0.05)$. These variables are good knowledge (OR=64.02; 95\% C.I. 4.998-670.120), side effects to antiretroviral therapy $(\mathrm{OR}=22.06 ; 95 \%$ C.I. 1.456-83.275), depression $(\mathrm{OR}=57.07$ (95\% C.I. 1.077-12.345), peer support (OR=46.01; 95\% C.I. 1.098-13.768), and availability of antiretroviral drugs $(\mathrm{OR}=12.18$; 95\% CI, 1.890-68.210) (Table 3).

\section{DISCUSSION}

There were 99 subjects analyzed in this study, i.e. all women who were infected with HIV/AIDS from their regular sexual partner/ spouse and had no history of drug/substance abuse. In Indonesia, it is predicted that the number of women infected with HIV/AIDS will be increasing. The Indonesian Ministry of Health reported in 2012, that the number of housewives infected with HIV will increase each year, while the number of commercial sex workers infected with HIV is declining. It is assumed that this results from transmitted HIV infection from their partner/spouse who have high-risk behavior. ${ }^{(3)}$

Antiretroviral therapy must be continued life long and adherence is necessary. ${ }^{(7)}$ This study showed that $57.6 \%$ of subjects had poor ART adherence $(<95 \%)$ and approximately $56 \%$ of subjects had a history of often receiving antiretroviral drugs not on schedule. ${ }^{(12)}$ Research in 2013 on 55 outpatients with HIV/AIDS at Dr M Djamil Hospital in Padang showed that 25.5\% subjects had low ART adherence $(<95 \%) .{ }^{(14)}$ The Indonesian Ministry of Health reported that in 2014, ART adherence in women who are infected with HIV/AIDS in Indonesia is still low. They often receive the antiretroviral drugs late or forget to take them on a regular basis, because they have to care for their children or the sick husband, to become the backbone of the family, to hide their HIV/ AIDS infection status from 
their children or other family members so that they have to take the medications furtively, and there are some hospital staff who behave less friendly to them when they come for health services. ${ }^{(15)}$

This study tested the most powerful factor in influencing adherence to ART. The findings in this study proved that the variable knowledge about HIV/AIDS and ART is the most powerful factor in influencing ART adherence. Multivariate statistical analysis with backward stepwise method showed a value of $\mathrm{OR}=64.02$ (CI 95\%: 4.998-670.120) on knowledge in the good category. Subjects who had knowledge about HIV/AIDS and whose ART adherence was good, tended to be 64 times more likely to have high ART adherence, compared with subjects with poor knowledge. The results of this study are in accordance with those the study of Martoni et al. ${ }^{(14)}$ which showed that the most dominant factor was knowledge associated with ART adherence in people infected with HIV/AIDS. People infected with HIV/AIDS with good knowledge about the infection rate of HIV/AIDS and its treatment have a 9 times greater probability to reach good ART adherence. Risha's ${ }^{(16)}$ study showed that a good knowledge about the disease and its treatment can provide support and motivation to carry out the treatment and taking medication. Women who are infected with HIV/AIDS and who have a good knowledge about HIV/AIDS and antiretroviral therapy will tend to have a good degree of ART adherence. They can also change their behavior to control disease conditions and adhere to treatment.

Multivariate statistical analysis with backward stepwise method showed subjects without depression have a 57 times higher tendency to have high ART adherence compared with subjects with depression. These results were similar to those of Jenna ${ }^{(17)}$ who reported a significant correlation between depression and ARV non-adherence. Depression affected patient's self-care and contributed to degradation of physical and mental health, causing someone to feel helpless, unworthy, hopeless, and to have a lesser degree of motivation to survive and to achieve therapy adherence, which may lead to decline of the immune system and exaggeration of HIV/AIDS. ${ }^{(18)}$ Mazzafero and Murray states that depression may be a predictor of poor ART adherence, increased sexual risk behavior, failure of antiretroviral treatment, HIV progression, and high mortality. People infected with HIV/AIDS who are depressed are almost twice as likely to have problems in adherence to antiretroviral therapy (ART) than those who do not experience depression. ${ }^{(19)}$ Research by Mary et al. ${ }^{(20)}$ showed that women infected with HIV/AIDS with chronic depressive symptoms have twice the risk of death than women without depression. Health professionals should maintain early detection of emotional mental disorders in women infected with HIV/AIDS in order for the disease to receive serious treatment and not to have a wide impact on the patients' health and life.

On multivariate statistical analysis with backward stepwise method it was found that subjects with peer support have a 46 times higher tendency to achieve high adherence compared with subjects without peer support. The role of peer support is very essential, i.e. helping patients living with HIV/AIDS to ease the loneliness and to deal with the problems, helping to build selfesteem and confidence, sharing resources, ideas and information (about benefits of ARV therapy, updated treatment, local health support, etc.) as well as affecting adherence to ART treatment. ${ }^{(21)}$ Another study reported that a peer support group, which is a group of two or more people infected with HIV/AIDS or those who have been directly affected, is significantly correlated with higher ART adherence. ${ }^{(22)}$

Multivariate statistical analysis with backward stepwise method showed that in subjects without experienced ART side effects, the probability of implementing ART adherence is 22.06 times higher than in subjects with experienced ART side effects. When people with HIV/AIDS at the start of therapy experience side effects and do not have education or good knowledge about the benefits and side effects of 
ART, they do not know how to overcome the side effects and do not have the skills to cope with the side effects, and may possibly feel reluctant to implement therapy in accordance with the rules or may even decide to quit the treatment, which will increase the numbers of those lost to follow-up or stopping therapy. ${ }^{(23)}$

Multivariate statistical analysis with backward stepwise method showed that subjects who were in the high category of ARV drugs availability were 12 times more likely to implement high ART adherence. The Indonesian Ministry of Health reported that the provision of antiretroviral drugs cannot be done at every desired location, since because antiretroviral drugs are expensive, their distribution should be regulated through locations that have been determined to be easily controlled. Drug policies to provide free antiretroviral drugs proved to have a substantial impact in reducing morbidity, mortality and increasing the quality of life of people living with HIV. ${ }^{(3,7)}$ Health care systems that are difficult to access, expensive health financing, muddled bureaucracy, and the availability of antiretroviral drugs in only a few hospitals as determined by the government could lead to patients having difficulty accessing antiretroviral therapy programs and may have an impact on poor ART adherence. ${ }^{(24)}$

In women infected with HIV/AIDS who have a good knowledge about HIV/AIDS, the benefits of ART adherence, ART side effects, and duration of antiretroviral treatment, it will be easier to change their perception and behavior towards HIV/AIDS and its treatment so as to prevent the occurrence of mental disorders and to achieve good ART adherence. Therefore, they need psycho-education and counseling on a regular basis to improve their knowledge and help overcome the psychological problems that occur in women infected with HIV/AIDS. Thus the global vision agreed upon by various countries in the world in the management and treatment of HIV / AIDS, which was to "Achieve Zero" (Getting to Zero) in 2015, comprising zero new HIV/AIDS infections, zero discrimination, and zero AIDS-related deaths, can be achieved. ${ }^{(6,16)}$

This study has limitations in that some respondents were not confident and were ashamed to be invited to communicate or when asked to fill out questionnaires. To address this, the researchers accompanied the respondents to fill out questionnaires and to be interviewed by nurses from the local hospital. Another limitation was the time required (around 35 minutes) for filling out the questionnaires and interviewing each respondent.

\section{CONFLICT OF INTEREST}

The authors report no conflict of interest.

\section{CONCLUSIONS}

The main factors affecting antiretroviral therapeutic adherence in women infected with HIV/AIDS in Dharmais Hospital was the patient's knowledge about therapy. Strict adherence to antiretroviral therapy is key to sustained HIV suppression, reduced risk of drug resistance, improved overall health, quality of life, and survival, as well as decreased risk of HIV transmission.

\section{ACKNOWLEDGEMENT}

We thank all women who were infected with HIV/AIDS through their partner/husband and received antiretroviral therapy in Dharmais Hospital, who were willing to participate in this research and all health care staff of Dharmais Hospital who have helped in this research.

\section{REFERENCES}

1. Joint United Nations Programme on HIV and AIDS (UNAIDS). Global AIDS response country progress report. Reporting period January 2010 to December 2011. Geneva: UNAIDS;2012.

2. Departemen Kesehatan R.I. Direktorat Jenderal Pemberantasan Penyakit Menular dan Penyehatan Lingkungan Langsung. Pedoman nasional tata laksana klinis infeksi HIV dan 
terapi antiretroviral pada orang dewasa. Jakarta: Departemen Kesehatan R.I. Direktorat Jenderal Pemberantasan Penyakit Menular dan Penyehatan Lingkungan Langsung;2010.

3. Departemen Kesehatan R.I. Direktorat Jenderal Pemberantasan Penyakit Menular dan Penyehatan Lingkungan Langsung. Statistik kasus HIV/AIDS di Indonesia dilaporkan sampai dengan Desember 2014. Jakarta: Departemen Kesehatan R.I. Direktorat Jenderal Pemberantasan Penyakit Menular dan Penyehatan Lingkungan Langsung;2015.

4. Bor R, Du Plessis P. The impact of HIV/AIDS on families: an overview of recent research. Am J Psychology 2011;15:413-27.

5. Penzack SR, Redy YS, Grimsely SR. Depression in patients with HIV/AIDS infection. Am J Health-Syst Pharm 2010;57:376-401.

6. World Health Organization, UNAIDS \& Komisi Penanggulangan AIDS Nasional. ODHA dan akses pelayanan kesehatan dasar di Indonesia. 2010-2014. Available at: http://www.spiritia.or.id /dokumen/odha-akses.pdf. Accessed December 9, 2014.

7. Filho LF, Nogueira SA, Machado ES, et al. Factors associated with lack of antiretroviral adherence among adolescents in a reference centre in Rio de Janeiro, Brazil. JIAS 2009;19: 685-8.

8. Valeri J, Surilena, Yanto B, et al. Family support is not a risk factor of self-esteem in HIV/AIDs women. Univ Med 2015;34:61-7.

9. Della. Cognitive behavior therapy untuk meningkatkan self-esteem pada mahasiswa Universitas Indonesia yang mengalami distres psikologis. [tesis]. Jakarta: Fakultas Psikologi, Universitas Indonesia;2012.

10. Hamilton M. Development of a rating scale for primary depressive illness. Am J Psychiatry 2009;8:233-9.

11. Sumanto R, Marsito. Hubungan tingkat nyeri dan tingkat kecemasan pada pasien post operasi section caesarea di RSU Gombong. J Ilmiah Kesehatan Keperawatan 2011;7:83-90.

12. Leserman J, Barroso J, Pence BW, et al. Trauma, stressful life events and depression predict HIVrelated fatigue. AIDS Care 2008;20:1258-65. doi: 10.1080/09540120801919410.
13. Surilena, Irawati R, Irwanto, et al. The effect of rational emotive behaviour therapy (REBT) on antiretroviral therapeutic adherence and mental health in women infected with HIV/AIDS. Acta Med Indones 2014;4:283-91.

14. Martoni W, Helmi A, Raveinal. Faktor-faktor yang mempengaruhi kepatuhan pasien HIV/ AIDS di poliklinik khusus rawat jalan Bagian Penyakit Dalam RSUP dr. M. Djamil Padang periode Desember 2011- Maret 2012. J Farmasi Andalas 2013;1:48-52.

15. Djauzi S. ARV for adult; implementation in primary health care. AIDS 2014;29:111-6.

16. Risha. Faktor-faktor yang mempengaruhi tingkat kepatuhan pengobatan ARV pada ODHA di Rumah Sakit Umum Daerah Tugu Rejo dan Rumah Sakit Umum Panti Wilasa Citarum Semarang. J Penelitian 2011;4:122-7.

17. Jenna M. Depression greatly impairs treatment adherence. JIAS 2010;7:321-42.

18. Folkman. Stress and coping caregiving partners of women with AIDS. Psychiatr Clin North America 2006;17:35-52.

19. Mazzafero KE, Murray PZ. Depression, stress, and social support as predictors of HIV/AIDS in young women. J Adolesc Health 2009;39:337-44.

20. Rotheram-Borus MJ, Stein JA, Jiraphongsa C, et al. Benefits of family and social relationships for Thai parents living with HIV. Prev Sci 2010; 11:298-307.

21. Kremer H, Ironson G, Porr M. Factors contributing to ARV non adherence among PLWHAA attending CTC at Ligula Hospital in Mtwara Region Tanzania. AIDS 2009;24:103135.

22. Filho LF, Nogueira SA, Machado ES, et al. Factors associated with lack of antiretroviral adherence among adolescents in a reference centre in Rio de Janeiro, Brazil. Int J STD AIDS 2008;19:685-8. doi: 10.1258/ijsa.2008.008017.

23. Tuldra A, Fumaz CR, Ferret M1J. Prospective randomized two-arm controlled study to determine the efficacy of a specific intervention to improve long-term adherence to highly active antiretroviral therapy. JIAS 2011;25:221-8.

24. Gifford AL, Bormann JE, Shively MJ, et al. Predictors of self-reported adherence and plasma HIV concentrations in patients on multidrug antiretroviral regimens. JIAS 2012;23:386-95. 